\title{
Evaluation of the influence of different beverages on the color stability of heat polymerized denture base acrylic resin materials
}

\author{
Chouksey $\mathbf{G}^{1}$, Roopa KT ${ }^{2}$, Dayal $\mathrm{D}^{3}$ \\ ${ }^{1}$ Dr. Gunjan Chouksey, MDS (Prosthodontist and Implantologist), Consultant Asian Institute of Oncology, Mumbai, ${ }^{2}$ Dr. \\ Roopa KT, MDS (Prosthodontist and Implantologist), Professor, Department of Prosthodontics, CODS, Davangere, ${ }^{3}$ Dr. \\ Divyank Dayal, MDS (Prosthodontist and Implantologist)
}

Address for Corresponding: Dr. Gunjan Chouksey. The Dental \& Maxillofacial Prosthetic Clinic, ASIAN INSTITUTE OF ONCOLOGY, K J Somaiya Hospital Campus, Off Eastern Express Highway, Sion, Mumbai. Email.gunjanc20@gmail.com

\begin{abstract}
Introduction: Denture base resin materials get discolored after coming in contact with beverages and food materials. Color stability provides important information on the serviceability of these materials. However, this property is often ignored over other physical and mechanical properties while making a choice of material. Methods and Material: 30 specimen disks (15 mm x $2 \mathrm{~mm}$ ) of Trevalon, DPI and Acralyn-H denture base resin materials were prepared. Color measurements were done with computer controlled CM-3310d Spectrophotometer (MINOLTA CM3310d) before immersion $\left(\mathrm{T}_{0}\right)$ and after 1 day $\left(\mathrm{T}_{1}\right), 7$ days $\left(\mathrm{T}_{2}\right), 1$ month $\left(\mathrm{T}_{3}\right)$ and 2 months $\left(\mathrm{T}_{4}\right)$ of immersion in Tea and Coffee solution. Averages of three readings were taken and the mean of each material were calculated with the use of CIELAB uniform color scale. Results: Comparison of $\Delta \mathrm{E}$ (color difference) values for the denture base specimens of Trevalon, DPI and Acralyn-H after immersion in coffee and tea solutions showed significant color change after 1 day, 7 days, 1 month and 2 month . Conclusions: Within the limitations of study it was found that Coffee and Tea cause considerable discoloration of denture base acrylic resin materials.
\end{abstract}

Keywords: Dental Materials, Color stability, Discolouration, Spectrophotometer, CIELAB, Beverages

\section{Introduction}

Acrylic resins are commonly used to fabricate denture bases because of their low cost, durability, easy manipulation and construction method [1]. However they have certain disadvantages like being hard, rigid, easy to fracture and prone to absorption and adsorption of liquids [2]. The absorption is due to the polar properties of resin molecules because of which the denture base resin materials are known to undergo staining through the use of denture cleansers and from the intake of oral fluids and foods [3]. Color stability is a required characteristic of denture base resin materials and provide important information on the serviceability of these materials. Color change is an indication of aging or damage to dental materials [4]. The habit of

Manuscript received: $25^{\text {th }}$ Nov 2015

Reviewed: $11^{\text {th }}$ Dec 2015

Author Corrected: $20^{\text {th }}$ Dec 2015

Accepted for Publication: $31^{\text {st }}$ Dec 2015 daily intake of beverages like tea, coffee several times a day tend to stain and discolor resins. Flavins in tea leaves and caffeine and caffeic acid in coffee leads to discoloration [5]. Both concentration of staining agent in beverages and the period of exposure affects the pigmentation of resins. Hence, minimizing color change is a factor that should be considered in selection of denture base materials and techniques.

With this knowledge in background, the present study was planned to evaluate the color stability of three different heat cured denture base acrylic resin materials after immersion in tea and coffee solutions.

\section{Aims and Objectives}


The aim of the study was to evaluate the influence of different beverages on the color stability of three different heat polymerized denture base acrylic resin materials. The objective of the study was to compare the color stability of three brands of heat polymerized denture base acrylic resin materials used for fabricating denture bases.

\section{Materials and Method}

30 specimen disks (15 mm x $2 \mathrm{~mm}$ ) were prepared of each material- TREVALON [ Dentsply India Pvt Ltd, Gurgaon, Haryana, India], DPI [ DPI, Bombay, India], ACRALYN-H [Asian Acrylates, Mumbai, India] (Fig. 1) using a silicone mold. The wax blocks were invested in the denture processing flask (Kavo, Germany) and processed according to manufacturer's instructions. After deflasking, surface irregularities on specimens and excess material were trimmed off with acrylic trimmer. All specimens were abraded on both sides with silicone carbide paper and finished. Polishing was done with pumice and water using a cloth wheel. The resultant surface was smooth and polished (Fig. 2). After finishing and polishing, the specimens were stored in distilled water at $37^{\circ} \mathrm{C} \pm 1{ }^{\circ} \mathrm{C}$ for 24 hours in the incubator. The rehydration simulated the first day of service for restoration in the oral environment. All the specimens from each denture base resin were dried with tissue paper and then each sample of resin was subjected to color measurement using computer controlled CM-3310d Spectrophotometer (MINOLTA CM3310d), before immersion $\left(\mathrm{T}_{0}\right)$ into the two staining solutions. Tea and Coffee solution were prepared by mixing $15 \mathrm{gm}$ of tea (Brooke Bond Taj Mahal) and 15 gm of coffee (Nestle, Nescafe) in $500 \mathrm{ml}$ of boiling distilled water for 10 minutes. The solutions were prepared fresh daily. The specimens were immersed in the solutions for total duration of 2 months. For statistical analysis specimens were grouped as follows:

\begin{tabular}{|l|l|l|l|}
\hline & Denture base resin A & Denture base resin B & Denture base resin C \\
\hline Distilled Water(control) & 10 & 10 & 10 \\
\hline Tea & 10 & 10 & 10 \\
\hline Coffee & 10 & 10 & 10 \\
\hline
\end{tabular}

After immersion of each specimen into 2 staining solutions, the values of color change were measured and calculated after 1 day $\left(\mathrm{T}_{1}\right), 7$ days $\left(\mathrm{T}_{2}\right), 1$ month $\left(\mathrm{T}_{3}\right)$ and 2 months $\left(\mathrm{T}_{4}\right)$ (Fig. 3,4,5) using computer controlled CM-3310d spectrophotometer. Before each measurement, specimens were cleaned in distilled water for 5 minutes and dried with tissue paper. Averages of three readings were taken and the mean of each material were calculated with the use of CIELAB uniform color scale. The testing apparatus had a measuring head aperture of $10 \mathrm{~mm}$ in diameter. The specimens were centered on the measuring head of the spectrophotometer. The CIELAB system is an approximately uniform color space with coordinates for lightness, namely, white-black (L), redness-greenness (a), and yellowness-blueness (b). This system makes it possible to evaluate the amount of perceptible color change in each sample. $\mathrm{L}, \mathrm{a}, \mathrm{b}$ values of each specimen before immersion $\left(\mathrm{T}_{0}\right)$ and after immersion at each specified time intervals $\left(T_{1}, T_{2}, T_{3}, T_{4}\right)$ were measured by placing each specimen on the measuring head and covering with the black cover. The mean values of $\Delta \mathrm{L}$, $\Delta \mathrm{a}$, and $\Delta \mathrm{b}$ after measurements were automatically calculated by the spectrophotometer and recorded. Color difference $(\Delta \mathrm{E})$ was calculated from the mean $\Delta \mathrm{L}, \Delta \mathrm{a}$, and $\Delta \mathrm{b}$ values for each specimen with the formula: $\Delta \mathrm{E}=\sqrt{ }\left(\Delta \mathrm{L}^{2}+\Delta \mathrm{a}^{2}+\Delta \mathrm{b}^{2}\right)$.

Mean and Standard Deviation of the obtained values was calculated. One way analysis of Variance (ANOVA) was used to compare the values within the groups. Scheffe's Post Hoc test was applied for pairwise comparison within the groups using Statistical Package for Social Sciences (SPSS, Chicago, Ill.) software version 17.0. 


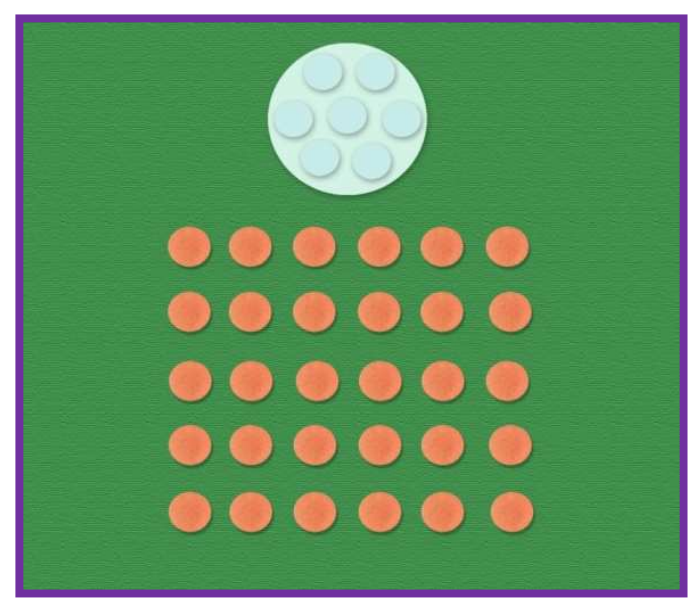

Fig. 1: Silicone mold and prepared wax samples.

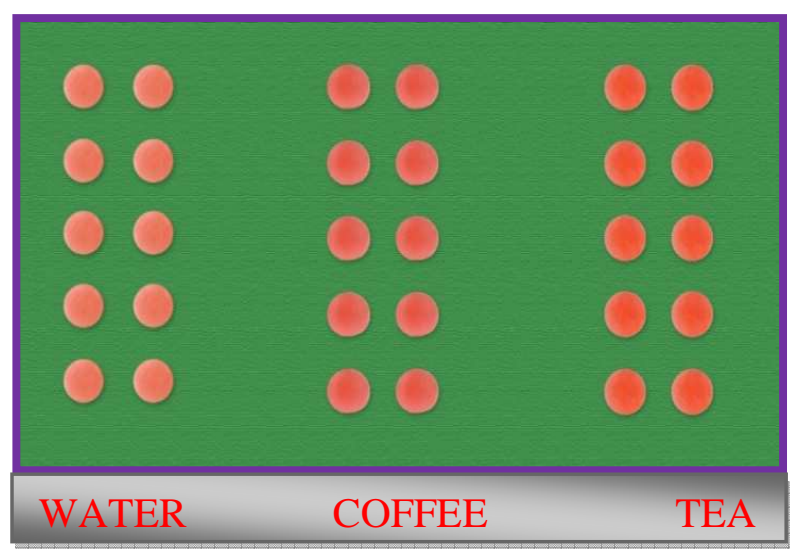

Fig. 3: Trevalon samples after 2 months of immersion.

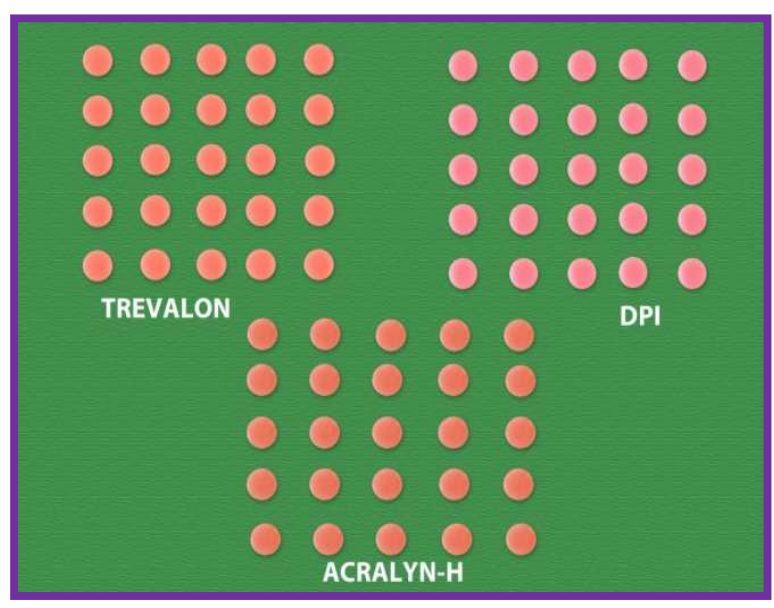

Fig. 2: Finished samples.

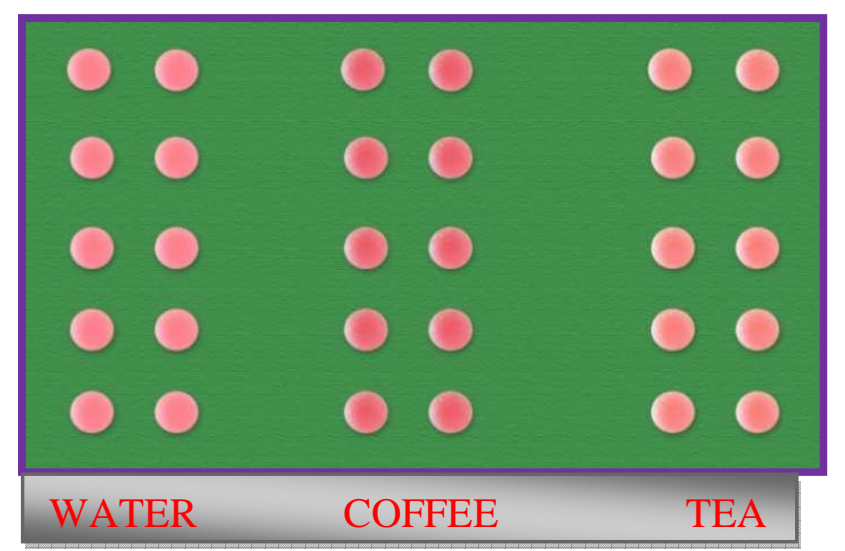

Fig.4: DPI samples after 2 months of immersion.

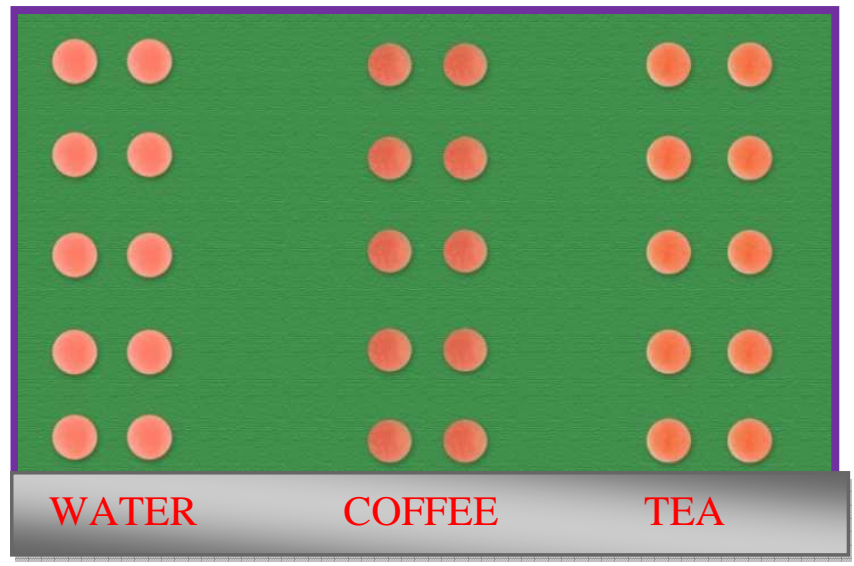

Fig 5: Acralyn-H samples after 2 months of immersion.

\section{Results}

Comparison of $\Delta \mathrm{E}$ values for water, coffee solution and tea solution for Trevalon, DPI and Acralyn-H denture base resin material was done ( Table 1,2,3). Both coffee solution and tea solution caused staining of the denture base resins after 1 day, 7 days, 1 month and 2 month interval. Table 4 depicts comparison of $\Delta \mathrm{E}$ values for the denture base specimens of 
Trevalon, DPI and Acralyn-H after immersion in water. No significant color difference was seen after 1 day , 7 days, 1 month and 2 months interval. Table 5 and Table 6 depicts comparison of $\Delta \mathrm{E}$ values for the denture base specimens of Trevalon, DPI and Acralyn-H after immersion in coffee and tea solutions respectively. Significant color change was seen after 1 day, 7 days, 1 month and 2 month .

Table 1: Comparison of $\Delta \mathbf{E}$ values for water, coffee and tea solutions for Trevalon

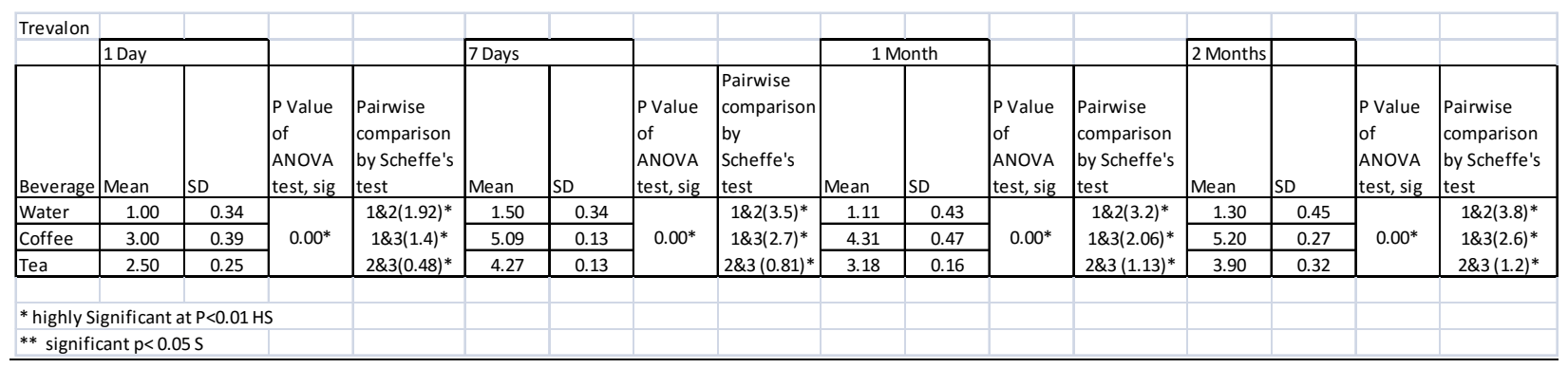

Table 2:_Comparison of $\Delta \mathbf{E}$ values for water, coffee and tea solutions for DPI

\begin{tabular}{|c|c|c|c|c|c|c|c|c|c|c|c|c|c|c|c|c|}
\hline \multicolumn{17}{|l|}{ DPI } \\
\hline & \multicolumn{2}{|l|}{1 Day } & & & \multicolumn{2}{|l|}{7 Days } & & \multirow[b]{2}{*}{\begin{tabular}{|l|} 
Pairwise \\
comparison \\
by \\
Scheffe's \\
test \\
\end{tabular}} & \multicolumn{2}{|c|}{1 Month } & & \multirow[b]{2}{*}{$\begin{array}{l}\text { Pairwise } \\
\text { comparison } \\
\text { by Scheffe's } \\
\text { test }\end{array}$} & \multirow[b]{2}{*}{\begin{tabular}{|l}
2 Months \\
\\
Mean \\
\end{tabular}} & & \multirow[b]{2}{*}{$\begin{array}{l}\text { P Value } \\
\text { of } \\
\text { ANOVA } \\
\text { test, sig } \\
\end{array}$} & \multirow[b]{2}{*}{$\begin{array}{l}\text { Pairwise } \\
\text { comparison } \\
\text { by Scheffe's } \\
\text { test }\end{array}$} \\
\hline Beverage & Mean & SD & $\begin{array}{l}\text { P Value } \\
\text { of } \\
\text { ANOVA } \\
\text { test, sig } \\
\end{array}$ & $\begin{array}{l}\text { Pairwise } \\
\text { comparison } \\
\text { by Scheffe's } \\
\text { test }\end{array}$ & Mean & SD & $\begin{array}{l}\text { P Value } \\
\text { of } \\
\text { ANOVA } \\
\text { test, sig }\end{array}$ & & Mean & SD & $\begin{array}{l}\text { P Value } \\
\text { of } \\
\text { ANOVA } \\
\text { test, sig } \\
\end{array}$ & & & SD & & \\
\hline Water & 0.90 & 0.24 & \multirow{3}{*}{$0.00^{*}$} & $1 \& 2(1.8)^{*}$ & 1.30 & 0.28 & \multirow{3}{*}{$0.00^{*}$} & $1 \& 2(3.4)^{*}$ & 1.00 & 0.28 & \multirow{3}{*}{$0.00^{*}$} & \multirow{3}{*}{\begin{tabular}{|c|}
$1 \& 2(2.9)^{*}$ \\
$1 \& 3(2.0)^{*}$ \\
$2 \& 3(0.87)^{*}$
\end{tabular}} & 1.30 & 0.27 & \multirow{3}{*}{$0.00^{*}$} & $1 \& 2(2.8)^{*}$ \\
\hline Coffee & 2.80 & 0.26 & & $1 \& 3(1.2)^{*}$ & 4.70 & 0.22 & & $1 \& 3(2.5)^{*}$ & 3.90 & 0.12 & & & 4.10 & 0.35 & & $1 \& 3(1.9)^{*}$ \\
\hline Tea & 2.20 & 0.28 & & $2 \& 3(0.57)^{*}$ & 3.80 & 0.30 & & $2 \& 3(0.92) *$ & 3.00 & 0.28 & & & 3.20 & 0.12 & & $2 \& 3(0.92)^{*}$ \\
\hline & & & & & & & & & & & & & & & & \\
\hline \multicolumn{17}{|c|}{ * highly Significant at $P<0.01 \mathrm{HS}$} \\
\hline ** signifi & cant $p<0$ & & & & & & & & & & & & & & & \\
\hline
\end{tabular}

Table 3: Comparison of $\Delta \mathbf{E}$ values for water, coffee and tea solutions for Acralyn-H

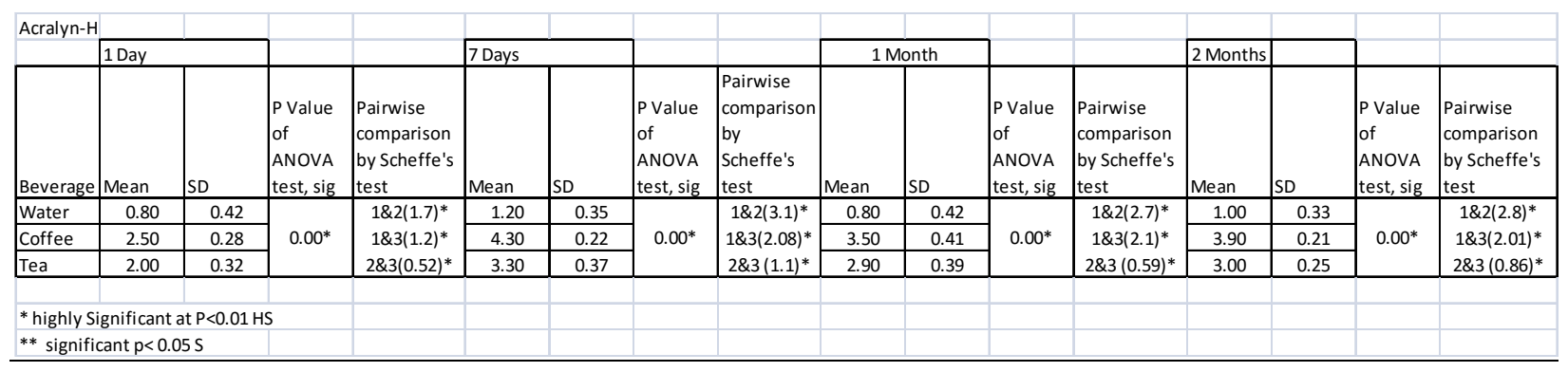

Table 4: Comparison of $\Delta \mathbf{E}$ values after immersion in water for the denture base specimens of Trevalon, DPI and Acralyn-H

\begin{tabular}{|c|c|c|c|c|c|c|c|c|c|c|c|c|c|c|c|c|}
\hline \multicolumn{17}{|l|}{ Water } \\
\hline & 1 Day & & & & 7 Days & & & & & onth & & & 2 Months & & & \\
\hline Groups & Mean & SD & $\begin{array}{l}\text { P Value } \\
\text { of } \\
\text { ANOVA } \\
\text { test, sig } \\
\end{array}$ & $\begin{array}{l}\text { Pairwise } \\
\text { comparison } \\
\text { by Scheffe's } \\
\text { test }\end{array}$ & Mean & SD & $\begin{array}{l}\text { P Value } \\
\text { of } \\
\text { ANOVA } \\
\text { test, sig } \\
\end{array}$ & \begin{tabular}{|l} 
Pairwise \\
comparison \\
by \\
Scheffe's \\
test \\
\end{tabular} & Mean & SD & $\begin{array}{l}\text { P Value } \\
\text { of } \\
\text { ANOVA } \\
\text { test, sig } \\
\end{array}$ & $\begin{array}{l}\text { Pairwise } \\
\text { comparison } \\
\text { by Scheffe's } \\
\text { test }\end{array}$ & Mean & SD & $\begin{array}{l}\text { P Value } \\
\text { of } \\
\text { ANOVA } \\
\text { test, sig } \\
\end{array}$ & $\begin{array}{l}\text { Pairwise } \\
\text { comparison } \\
\text { by Scheffe's } \\
\text { test }\end{array}$ \\
\hline \begin{tabular}{|l|} 
Trevalon \\
\end{tabular} & 1.00 & 0.34 & \multirow{3}{*}{ NS } & \multirow[t]{3}{*}{-} & 1.50 & 0.34 & \multirow{3}{*}{ NS } & - & 1.10 & 0.43 & \multirow{3}{*}{ NS } & - & 1.30 & 0.45 & \multirow{3}{*}{ NS } & \multirow[t]{3}{*}{ - } \\
\hline DPI & 0.90 & 0.24 & & & 1.30 & 0.28 & & & 1.00 & 0.28 & & & 1.30 & 0.27 & & \\
\hline Acralyn-H & 0.80 & 0.42 & & & 1.20 & 0.35 & & & 0.80 & 0.42 & & & 1.00 & 0.33 & & \\
\hline
\end{tabular}

NS = Non Significant. 
Table 5: Comparison of $\Delta \mathbf{E}$ values after immersion in coffee solution for the denture base specimens of Trevalon, DPI and Acralyn-H

\begin{tabular}{|c|c|c|c|c|c|c|c|c|c|c|c|c|c|c|c|c|}
\hline \multicolumn{17}{|l|}{ Coffee } \\
\hline & \multicolumn{2}{|l|}{1 Day } & & & \multicolumn{2}{|l|}{7 Days } & & & \multicolumn{2}{|c|}{1 Month } & & & 2 Months & & & \\
\hline Groups & Mean & SD & $\begin{array}{l}\text { P Value } \\
\text { of } \\
\text { ANOVA } \\
\text { test, sig }\end{array}$ & $\begin{array}{l}\text { Pairwise } \\
\text { comparison } \\
\text { by Scheffe's } \\
\text { test }\end{array}$ & Mean & SD & $\begin{array}{l}\text { P Value } \\
\text { of } \\
\text { ANOVA } \\
\text { test, sig }\end{array}$ & $\begin{array}{l}\text { Pairwise } \\
\text { comparison } \\
\text { by } \\
\text { Scheffe's } \\
\text { test }\end{array}$ & Mean & SD & $\begin{array}{l}\text { P Value } \\
\text { of } \\
\text { ANOVA } \\
\text { test, sig }\end{array}$ & $\begin{array}{l}\text { Pairwise } \\
\text { comparison } \\
\text { by Scheffe's } \\
\text { test }\end{array}$ & Mean & SD & $\begin{array}{l}\text { P Value } \\
\text { of } \\
\text { ANOVA } \\
\text { test, sig }\end{array}$ & $\begin{array}{l}\text { Pairwise } \\
\text { comparison } \\
\text { by Scheffe's } \\
\text { test }\end{array}$ \\
\hline Trevalon & 3.00 & 0.39 & \multirow{3}{*}{$0.01^{* *}$} & \multirow{3}{*}{$\begin{array}{c}1 \& 2(0.18) \\
1 \& 3(0.48)^{* *} \\
2 \& 3(0.3) \\
\end{array}$} & 5.10 & 0.13 & \multirow{3}{*}{$0.01^{* *}$} & $1 \& 2(0.36)^{*}$ & 4.30 & 0.47 & \multirow{3}{*}{$0.00^{*}$} & \multirow{3}{*}{\begin{tabular}{c|}
$1 \& 2(0.4)$ \\
$1 \& 3(0.8)^{*}$ \\
$2 \& 3(0.42)$ \\
\end{tabular}} & 5.20 & 0.27 & \multirow{3}{*}{$0.01^{* *}$} & $1 \& 2(1.08)^{* *}$ \\
\hline DPI & 2.80 & 0.26 & & & 4.70 & 0.22 & & $1 \& 3(0.78)^{* *}$ & 3.90 & 0.12 & & & 4.10 & 0.35 & & $1 \& 3(1.31)^{*}$ \\
\hline Acralyn-H & 2.50 & 0.28 & & & 4.30 & 0.22 & & $2 \& 3(0.42)^{*}$ & 3.50 & 0.41 & & & 3.90 & 0.21 & & $2 \& 3(0.42)$ \\
\hline \multicolumn{17}{|c|}{ * highly Significant at $P<0.01 \mathrm{HS}$} \\
\hline ** signific & cant $p<0$ & & & & & & & & & & & & & & & \\
\hline
\end{tabular}

Table 6: Comparison of $\Delta \mathbf{E}$ values after immersion in tea solutios for the denture base specimens of Trevalon, DPI and Acralyn-H

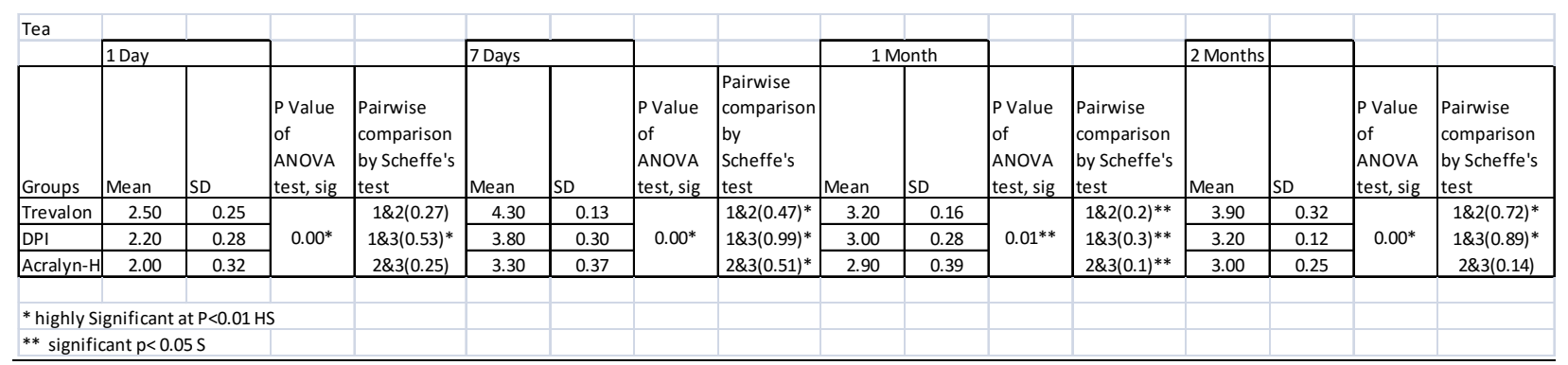

\section{Discussion}

Color stability of a material can be evaluated by various methods. It involves subjecting the specimens to a colorant and evaluating the change in color over a period of time. Color evaluation can be performed visually (Munsell system) or by using a spectrophotometer and colorimeter (CIELAB system) $[6,7,8,9,10]$. Commision Internationale de L'Eclairage (CIELAB) system is a uniform 3 dimensional system that determines color changes. Variability of results by visual assessment can arise due to several factors including the observed object, illuminant position relative to the observer and to each other, color characteristics of the illuminant, metamerism, fatigue, aging and emotional state of the observer [6,11]. Instrument measurements can eliminate subjective interpretation of visual color comparison, hence spectrophotometers and colorimeters are more widely used today. Discoloration of materials may be caused by intrinsic or extrinsic factors. Intrinsic factors involve chemical changes of the material due to the oxidation of amine accelerators by a change in hue from whitish to yellow appearance. Extrinsic factors of discoloration include staining by adhesion or penetration of colorants from exogenous sources like coffee, tea, nicotine etc [6]. Hydrophilic materials show a higher degree of water sorption and a relatively higher discoloration value with staining solutions than hydrophobic materials [6,12]. PMMA exhibits a water sorption value of $0.69 \mathrm{mg} / \mathrm{cm}^{2}$. [13] Liquid intake specially causes surface staining, [14] Hence, these beverages were selected for the study. Guler et al [14] described that coffee consumption ( 1 dose) lasts $15 \mathrm{~min}$, given that 3.2 doses are consumed daily by regular coffee drinkers. Thus, the 24-h storage simulate 1 month of regular coffee drinking. In this study, the same immersion time for coffee and tea was used. Thus, the immersion period of 7 days, 1 month and 2 months represents 7 months, 2.5 years and 5 years of consumption respectively. The time periods chosen in this study is considered as the cumulative time for few years of consuming the drinks within short period of time. This is suitable for the denture base resin material which might get stained after few years of fabrication. According to present study,_after 1 day, 7 days, 1 month and 2 months of immersion, both coffee solution and tea solution caused staining of the denture base resins. Coffee solution stained the denture base resin materials more than tea. According to Nur Hersek et al [1] tannic acid present in tea and coffee caused the staining. Imirzalioglu $\mathrm{P}$ et al [5] stated that tea flavins in tea leaves and caffeine and caffeic acid in coffee lead to discoloration in polymeric materials. Um and Ruyter [2,7] reported that discoloration due to tea can be easily removed, as discoloration of materials by tea is mainly due to 
surface adsorption of the colorants. In contrast, with coffee, the discoloration is probably due to both surface adsorption and absorption of colorants. It was also reported that fewer polar colorants from coffee had penetrated deeper into the materials because the colorants were more compatible with the polymer matrices of the resin materials. The materials with high value for water sorption showed relatively high discoloration values in all staining solutions. Lai et al[2] reported that hydrophobic materials are more prone to staining by hydrophobic solutions. Adversely, in the present study, coffee (hydrophobic solution) had a significant effect on the color of acrylic resins (hydrophilic material). Similar findings were noted in previous studies. Buyukyilmaz and Rruyter[2,15], Imirzalioglu $\mathrm{P}[5]$ demonstrated that coffee produced greater color changes than tea on denture base resins. Keskin investigated the color stability of PMMA denture base polymers after immersion in coffee and tea solutions for 7 days and reported an initial increase, then a decrease, in the discoloration values of the materials which was attributed to the removal of accumulated layer. As tea and coffee layers on specimens reach a certain thickness, they tend to break away from the surface of the specimens and return to the solution.[5] Similarly, the results obtained from the present study supported this aforementioned phenomenon. So it is assumed from the present study that coffee stains are absorbed more than tea stains may be because of the difference in particle size and deeper penetration of coffee stains than tea stains. Amongst the three denture base resin materials tested, Trevalon showed highest color change followed by DPI and Acralyn- $\mathrm{H}$ after immersion in coffee and tea solution. The difference in the color stability of denture base resin materials may be attributed to the difference in composition of tested denture base resin materials i.e. its nature (polar properties etc), which attribute to adsorption and absorption of staining solution.[7] and brands and strength of staining solutions.[16] Since in the present study all the specimens were immersed in same brands and strength of staining solution, the difference in color stability may be attributed mainly to difference in composition and polar properties of the materials. According to Tsuboi et al[17] acrylic resin contains a small number of carbonyl groups which are polar groups that attract water molecules. Water molecules on the surface of acrylic resin are pulled towards the polar residues inside the acrylic resin, spread through the intermolecular gaps of the resin, and gradually infiltrate deeper into the acrylic resin. The amount of water absorbed depends on the number of hydrophilic groups (carbonyl groups) in the acrylic resin polymer. Miettinen et al [18] stated that water is absorbed into polymer by the polarity of the molecules in the polymers, by unsaturated bonds of the molecules or unbalanced intermolecular forces in the polymers. Bettencourt et al[19] stated two conditions that influence the amount of water diffusion into denture resins. One is the water diffusion coefficient of the material that affects the time needed for its saturation with water and the amount of residual components that are released into the medium and replaced by water molecules. The difference in the chemistry of the resins may account for the different effect water immersion has on their properties. According to Tuna et al[20] the extent and rate of water uptake into polymer networks are predominantly controlled by resin polarity, dictated by the concentration of polar sites available to form hydrogen bonds with water. The present study revealed that both the beverages affect the color of the resins significantly when compared with the control group. Time was found to be a critical factor for color stability of acrylic denture base resin materials. The present study also revealed that amongst the three denture base materials tested Trevalon showed more color change after 1 day, 7days, 1 month and 2 months of immersion in staining solution followed by DPI and Acralyn-H.

\section{Conclusion}

Within the limitations of study, the following conclusions were drawn:

1) Coffee and tea cause considerable discoloration of denture base acrylic resin materials.

2) Coffee solution exhibited more discoloration followed by tea solution.

3) The maximum color difference was noted for Trevalon in both coffee and tea solutions after 1day, 7 days, 1 month and 2 months immersion period.

4) Acralyn-H exhibits better color stability than Trevalon and DPI over 1day, 7 days, 1 month and 2 months immersion period in the coffee and tea staining solutions.

\section{Funding:Nil. Conflict of interest: Nil. Permission for IRB: Yes}

\section{References}

1. Hersek N, Canay S, Uzun G, Yildiz F. Color stability of denture base acrylic resins in three food colorants. J Prosthet Dent. 1999 Apr;81(4):375-9. 


\section{Lai YL, Lui HF, Lee SY. In}

vitro color stability, stain resistance and water sorption of four removable gingival flange materials. J Prosthet Dent. 2003 Sep;90(3):293-300.

3. Keyf F, Etikan I. Evaluation of gloss changes of two denture acrylic resin materials in four different beverages. Dent Mater. 2004 Mar;20(3):244-51.

4. Hong G, Murata H, Li Y, Sadamori S, Hamada T. Influence of denture cleansers on the color stability of three types of denture base acrylic resin. J Prosthet Dent. 2009 Mar;101(3):205-13. doi: 10.1016/S00223913(09)60032-9.

5. Imirzalioglu P, Karacaer O, Yilmaz B, Ozmen Msc I. Color stability of denture acrylic resins and a soft lining material against tea, coffee, and nicotine. $\mathrm{J}$

Prosthodont. 2010 Feb;19(2):118-24. doi:

10.1111/j.1532-849X.2009.00535.x. Epub 2009 Dec 3.

6. Padiyar N, Kaurani P. Color stability: An important physical property of esthetic restorative materials. Int $\mathbf{J}$ Clin Dentl Sci 2010;1(1):81-4.

7. Um CM, Ruyter IE. Staining of resin-based veneering materials with coffee and tea. Quintessence Int. 1991 May;22(5):377-86.

8. Assunção WG, Barão VA, Pita MS, Goiato MC. Effect of polymerization methods and thermal cycling on color stability of acrylic resin denture teeth. J Prosthet Dent. 2009 Dec;102(6):385-92. doi: 10.1016/S0022-3913(09)60200-6.

9. Anusavice KJ. Phillip's. Science of dental materials. $11^{\text {th }}$ ed. Philadelphia: W.B. Saunders; 2003. p. 46-52.

10. Ferracane JL. Materials in dentistry Principles and Applications $2^{\text {nd }}$ ed St. Louis, Wolters Kluwer Co. 2001. p. 25.
11. Khokhar ZA, Razzoog ME, Yaman P. Color stability of restorative resins. Quintessence Int. 1991 Sep;22(9):733-7.

12. Bagheri R, Burrow MF, Tyas M. Influence of foodsimulating solutions and surface finish on susceptibility to staining of aesthetic restorative materials. J

Dent. 2005 May;33(5):389-98. Epub 2004 Dec 9.

13. Anusavice KJ. Phillip's. Science of dental materials. $10^{\text {th }}$ ed. Philadelphia: W.B. Saunders; 1996. p. 249.

14. Leite VM, Pisani MX, Paranhos HF, Souza $\mathrm{RF}$, Silva-Lovato $\mathrm{CH}$. Effect of ageing and immersion in different beverages on properties of denture lining materials. J Appl Oral Sci. 2010 Jul-Aug;18(4):372-8.

15. Buyukyilmaz S, Ruyter IE. Color stability of denture base polymers. Int J Prosthodont. 1994 JulAug;7(4):372-82.

16. Yannikakis SA, Zissis AJ, Polyzois GL, Caroni C. Color stability of provisional resin restorative materials. J Prosthet Dent. 1998 Nov;80(5):533-9.

17. Tsuboi A, Ozawa K, Watanabe M. Water absorption characteristics of two types of acrylic resin obturators. J Prosthet Dent. 2005 Oct;94(4):382-8.

18. Miettinen VM, Vallittu PK, Docent DT. Water sorption and solubility of glass fiber-reinforced denture polymethyl methacrylate resin. J Prosthet Dent. 1997 May;77(5):531-4.

19. Bettencourt AF, Neves CB, de Almeida MS, Pinheiro LM, Oliveira SA, Lopes LP, Castro MF. Biodegradation of acrylic based resins: A review. Dent Mater. 2010 May;26(5):e171-80. doi: 10.1016/j.dental.2010.01.006. Epub 2010 Feb 26.

20. Tuna SH, Keyf F, Gumus HO, Uzun C. The evaluation of water sorption/solubility on various acrylic resins. Eur J Dent. 2008 Jul;2(3):191-7.

\section{How to cite this article?}

Chouksey G, Roopa KT, Dayal D. Evaluation of the influence of different beverages on the color stability of heat polymerized denture base acrylic resin materials. Int $J$ Med Res Rev 2015;3(11):1363-1369. doi: 10.17511/ijmrr.2015.i11.247. 